\section{Work engagement: Individual and situational antecedents and its relationship with turnover intention}

\author{
Lucia Barbosa de Oliveira \\ Juliana da Costa Rocha \\ School of Economics and Finance, Ibmec, Rio de Janeiro, RJ, Brazil
}

\begin{abstract}
Purpose - The aim of the study was to analyze individual and situational antecedents of work engagement. More specifically, we propose that engagement is influenced by individual differences, measured by a construct called core self-evaluations, by human resource management practices, and by leader-member exchange quality. Moreover, we investigate the relationship between engagement and turnover intention.
\end{abstract}

Design/methodology/approach - The hypotheses were tested through multiple regression analysis with a sample of 299 professionals employed by public and private organizations of different sizes and sectors of the Brazilian economy.

Findings - All hypotheses were confirmed. More specifically, work engagement was positive and significantly related to participants' core self-evaluations, human resource management practices, and leadermember exchange quality. A negative and significant relationship between engagement and turnover intention was also found.

Originality/value - Results showed that both HR practices and leader-member exchange quality can influence employee engagement, highlighting the importance of investments in these fields. Since engagement was also associated with individual differences, establishing an engaged workforce might require selection strategies that privilege employees who are more positive about themselves.

Keywords - Work engagement; human resource management; leadermember exchange; core self-evaluations; turnover intention.
Received on

07/13/2016

Approved on

02/08/2017

Responsible editor:

Prof. Dr. João Maurício Gama

Boaventura

Evaluation process:

Double Blind Review

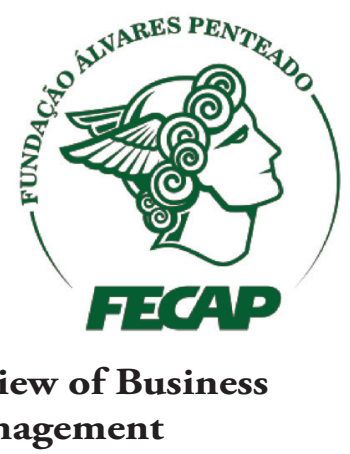

DOI: $10.7819 /$ rbgn.v19i64.3373 


\section{Introduction}

Human resource management is of utmost importance for the survival, growth and competitiveness of organizations, given that their human resources involve unique combinations of knowledge and skills that may bring a competitive differential (Barney \& Wright, 1998; Guerrero \& Barraud-Didier, 2004). Over the last decades, understanding the determinants of work engagement has been a concern for both human resource managers and researchers, due to evidence showing that focused and energized employees, willing to give their best at work, may give important contributions to business results (Kahn, 1990; Bakker, Albrecht, \& Leiter, 2011).

In this sense, the objective of this study was to evaluate antecedents of work engagement, including both individual characteristics and situational factors. Regarding individual characteristics, we investigated the relationship between engagement and core self-evaluations, which encompass self-esteem, self-efficacy, locus of control, and emotional stability (Judge, Erez, Bono, \& Thoresen, 2003). The situational factors considered were employees' perceptions regarding their organization's human resource management practices, and the quality of their relationship with their immediate superiors. Finally, we also analyzed the relationship between engagement and turnover intention.

Quantitative research was conducted with a sample of 299 employees who had undergone higher education, employed by public and private organizations of different sizes and sectors of the Brazilian economy.

The relevance of the study lies in its contribution to the literature on work engagement, a topic that has received relatively little attention from Brazilian researchers, despite its popularity among practitioners. Evidence indicates that work engagement has positive effects on individual and organizational performance (Bakker, Demerouti, \& Sanz-Vergel, 2014; Christian, Garza, \& Slaughter, 2011), which also makes studies on the subject relevant. In addition, the study innovates by simultaneously analyzing individual characteristics and situational aspects associated with work engagement, as the job demandsresources (JD-R) model points out (Bakker \& Demerouti, 2007). In our literature review, we did not find any studies based on this approach conducted in Brazil. From an applied perspective, the results may help guide human resource professionals who wish to create a work environment that fosters the engagement of employees.

\section{Theoretical background}

\section{I Work engagement}

Various definitions of work engagement can be found in the literature. Common to most of them is the idea that engagement is associated with a desirable condition that promotes individual and organizational performance. Kahn (1990), one of the pioneers in the study of this construct (Shuck \& Wollard, 2010), describes engaged employees as those who are physically, cognitively, and emotionally connected with their roles at work.

For this study, engagement was defined as a positive and rewarding work-related psychological state, characterized by vigor, dedication, and absorption, as proposed by Schaufeli, Salanova, Gonzales-Roma, and Bakker (2002). Vigor refers to high levels of energy, resilience and persistence, even when problems at work arise. Dedication is associated with a sense of meaning, enthusiasm, and pride while working. Absorption, in turn, involves a state of total concentration, happiness, and immersion at work, in which time passes quickly and from which it is difficult to fully detach (Salanova, Agut, \& Peiró, 2005; Schaufeli et al., 2002).

Because it is relatively recent, there is a debate over whether engagement is different from other positive concepts which measure an employee's relationship with his/her work (Christian et al., 2011; Hallberg \& Schaufeli, 
2006; Macey and Schneider, 2008), or if it is only "old wine in a new bottle" (Saks, 2006, p. 601). Regarding job satisfaction, Bakker (2011) argues that the concepts are different, since engagement combines a high level of pleasure at work (dedication) with high activation (vigor, absorption), while job satisfaction is supposedly a more passive form of well-being. In other words, in this case, the degree of activation or energy associated with engagement is greater than that of satisfaction (Macey \& Schneider, 2008; Warr \& Inceoglu, 2012).

Christian et al. (2011) quantitatively analyzed the relationship between work engagement, job satisfaction, job involvement, and organizational commitment. The evidence showed that, although there is a correlation between these constructs, engagement provides a relevant contribution to organizational studies. The authors point out that "the extent to which individuals invest their 'full selves' in the execution of their work appears to be a different concept from the extent to which individuals are satisfied with their jobs or value their organizations" (Christian et al., 2011, p. 120). Similarly, the study by Hallberg and Schaufeli (2006) also showed that work engagement, work involvement, and organizational commitment are different constructs. Finally, Bakker et al. (2011) point out that there is sufficient evidence to consider engagement as an important motivational construct independent from job satisfaction, organizational commitment, and organizational citizenship behavior. According to the authors, these constructs are, in reality, consequences of engagement.

Research on engagement has sought to identify its antecedents and consequents. Regarding the consequences of engagement, the literature has pointed out relationships between engagement and various positive effects, both individual and organizational. Engaged individuals invest more in their physical, cognitive and emotional development, and are more likely to have superior performance. They work harder because they are more focused on their responsibilities and are more emotionally attached to their tasks (Rich, Lepine, \& Crawford, 2010; Bakker et al., 2014). Evidence also indicates that engaged employees show higher levels of extra-role behavior, performing actions that go beyond their responsibilities (Bakker et al., 2014).

In relation to the antecedents of engagement, Kahn (1990) associated engagement with the context of work and individual characteristics. Similarly, the job demandsresources model establishes that personal resources and job resources are antecedents of engagement, and that job demands could contribute to exhaustion and burnout (Bakker \& Demerouti, 2007; Bakker et al., 2014).

Personal resources may be defined as positive self-assessments associated with an individual's ability to control and positively affect the environment, contributing to goal setting, motivation, performance, life satisfaction, and other desirable outcomes, including engagement (Bakker et al., 2014). Among the personal resources evaluated in the literature, self-esteem, self-efficacy, optimism, and internal locus of control were identified as positive antecedents of work engagement (Bakker \& Demerouti, 2008; Bakker, 2011; Xanthopoulou, Bakker, Demerouti \& Schaufeli, 2007; 2009).

Judge et al. (1997) proposed a construct called core self-evaluations, associated with assessments that individuals make of themselves, the world, and others, which would have an important influence on their levels of job satisfaction and performance. According to the authors, different perceptions and behaviors are affected by these self-evaluations, although most people are not aware of this influence. Individuals with positive core self-evaluations evaluate themselves favorably in different situations, that is, they see themselves as capable, valuable, and in control of their own lives.

The core self-evaluations construct is composed by four traits: (1) self-esteem, or the degree to which one sees oneself as capable and 
valuable; (2) generalized self-efficacy, or the judgment about one's ability to mobilize cognitive resources and adopt strategies to deal with specific situations; (3) locus of control, or one's belief regarding one's ability to exercise control over events one experiences; (4) neuroticism (the opposite of emotional stability), a personality trait that involves the tendency to experience negative feelings such as anxiety, fear, and depression (Judge et al., 1997; Bono \& Judge, 2003).

Although initial research on core self-evaluations has been directed towards job satisfaction, its literature has increased considerably, including studies on its relationship with motivation, work performance (Bono \& Judge, 2003; Erez \& Judge, 2001), and engagement (Rich et al., 2010). In line with Rich et al. (2010) - the first to evaluate the relationship between core self-evaluations and engagement we also propose a positive relationship between these two constructs.

H1: An employee's core self-evaluations are positively related to his/her engagement.

Regarding work-related resources, Macey and Schneider (2008) point out that work characteristics (e.g. challenge, variety and autonomy) and leadership influence engagement. Peer social support, the nature of leadership, and leader-member exchange quality were also identified as antecedents of engagement (Bakker, 2011; Bakker et al., 2014). Rich et al. (2010) found evidence that perceived organizational support and value congruence contribute to engagement. In short, resource-rich work environments tend to foster work engagement (Bakker, 2011; Bakker et al., 2011).

In this research, we propose that perceptions of HR management practices and leader-member exchange quality (LMX), which are variables related to work resources, are antecedents of engagement. In addition, we also examine the relationship between engagement and intention to quit. These topics are detailed below.

\subsection{Human Resource management systems}

The literature on strategic human resource management discusses the importance of developing HR policies and practices that are consistent with each other and contribute towards the organization's strategic objectives. This set of practices has been called high performance work systems (HPWS), high involvement HR systems, and other similar denominations (Lepak, Liao, Chung, \& Harden, 2006). Research in this field has sought to investigate HR systems' effects on individual attitudes and behaviors, as well as on organizational performance (Jiang, Lepak, Hu, \& Baer, 2012a).

However, there seems to be little consensus among researchers about which practices should be considered when designing a high performance HR system (Jiang, Lepak, Han, Hong, Kim, \& Winkler, 2012b). Furthermore, the mechanism through which these practices affect organizational performance remains a "black box." In other words, there is no precise and systematic explanation for the effects of HR systems on organizational effectiveness (Sun, Aryee, \& Law, 2007).

In this study, we took into consideration the approach proposed by Jiang et al. (2012a, $2012 \mathrm{~b}$ ), based on the abilities-motivationopportunities model, according to which the performance of employees is a function of their knowledge, skills, and abilities (KSAs), their motivation and effort, and the opportunities to contribute. The HR practices associated with each component are highlighted in Table 1. 
Table 1

HR management practices

\begin{tabular}{ll}
\hline Impact on & HR management practices \\
\hline KSAs & $\begin{array}{l}\text { Recruitment, selection, training and development. } \\
\text { Motivation and effort }\end{array}$ \\
$\begin{array}{l}\text { Performance appraisal, compensation, incentive, benefit, promotion and career development, and job } \\
\text { security. }\end{array}$ \\
Opportunities to contribute & $\begin{array}{l}\text { Job design, work teams, employee involvement, formal grievance and complaint processes, and } \\
\text { information sharing. }\end{array}$ \\
\hline
\end{tabular}

Fonte: Jiang et al. (2012a).

According to this model, recruitment, selection, training, and development practices contribute to the creation of a qualified workforce. Performance appraisal systems, competitive compensation, performance-based rewards, career development opportunities and internal mobility, as well as job security, would promote employee motivation and effort. It would also be important to create opportunities for contribution through practices such as teamwork and flexible work, employee involvement policies, and information sharing (Lepak et al., 2006; Jiang et al., 2012a, 2012b).

Considering that the adoption of high performance $\mathrm{HR}$ practices by an organization tends to increase job resources available to employees, we propose the following hypothesis:

H2: An employee's perception about highperformance HR practices is positively related to his/her engagement.

\subsection{Leader-member exchange theory}

In the workplace, several factors can affect employees' behaviors and attitudes, including their superior's leadership style and the quality of their relationship with their superiors. According to Den Hartog, Boon, Verburg, and Croon (2013), the actions of managers can be as - or more important than - the content of HR practices, considering that they are the main filter of information and the connection between written HR policies and what actually occurs.

The importance of leadership in organizational environments has attracted the interest of countless scholars. Research shows that it is possible to investigate leadership through different levels of analysis, including the individual level, the dyadic level - which addresses the interaction between leader and member -, and the group/organizational level (Graen \& Uhl-Bien, 1995).

The leader-member exchange (LMX) theory was originally developed by Graen, Dansereau, Cashman and Haga, in 1975. It was based on research that pointed out the existence of different kinds of relationship between leaders and subordinates, as opposed to the prevailing approach - which assumed that leaders presented constant behavior towards all subordinates (Graen \& Uhl-Bien, 1995; Schriesheim, Castro, \& Cogilser, 1999).

According to LMX theory, leaders establish a special, high-quality relationship with a small group of members (in-group), and tend to give less attention and maintain a formal relationship with other members (out-group). While the relationship with members of the in-group is characterized by trust, open communication, mutual respect and influence, relationship with out-group members tends to be limited to strictly transactional aspects (Gerstner \& Day, 1997; Graen \& Uhl-Bien, 1995). Gerstner and Day (1997) point out that leader-member exchange quality predicts individual, group, and organizational outcomes.

According to Schriesheim et al. (1999), interest in LMX theory has increased substantially over recent decades, and research has shown that subordinates engaged in high-quality 
relationships tend to be more satisfied, productive, and have positive discretionary behaviors, such as organizational citizenship behavior. In line with this evidence, we propose the following hypothesis:

H3: Leader-member exchange quality is positively related to employee engagement.

\subsection{Turnover intention}

Turnover intention is a well-researched topic. Many authors have studied its close relationship with voluntary turnover as well as the costs associated with the unexpected loss of employees. In addition to the costs related to recruitment, selection, and training of new employees, the literature also emphasizes the loss of explicit and essential tacit knowledge, built over time through socially complex mechanisms (Barney \& Wright, 1998; Cascio \& Boudreau, 2010). Furthermore, turnover causes disruption to an organization's operations, potentially leading to a decrease in sales and loss of customers (Cascio \& Boudreau, 2010).

In the literature on the antecedents of turnover intention and turnover itself, evidence points to general job satisfaction, satisfaction with different job characteristics, as well as external variables, such as perceived job alternatives (Griffeth, Hom, \& Gaertner, 2000; Hom, Caranikas-Walker, Prussia, \& Griffeth, 1992). Organizational justice, organizational commitment, and work engagement are also considered antecedents of turnover intention (Alfes, Shantz, Truss, \& Soane, 2013; Colquitt, Conlon, Wesson, Porter, \& Ng, 2001; Harter, Schmidt, \& Hayes, 2002; Tett \& Meyer, 1993). According to the literature, we propose a negative relationship between engagement and turnover intention.

H4: Employee engagement is negatively related to turnover intention.

\section{Method}

\section{I Procedure and sample}

This quantitative study was carried out with a sample of college-educated Brazilian workers, former or actual graduate students (lato sensu and stricto sensu) from a business school in Rio de Janeiro, employed in private and public organizations of different sizes and sectors.

The questionnaire was developed was carried out on the Survey Monkey ${ }^{\oplus}$ platform, and invitations to participate were sent by e-mail with a link. Potential participants were informed that this was an academic study, and that individual respondents could not be identified.

Among the approximately 3,500 individuals who were invited to take part in the research, 531 accessed the questionnaire (15\%). Respondents eligible to participate in the survey totaled 446 or $84 \%$ of that total. The others did not match the target audience because they were either unemployed, self-employed, entrepreneurs, students, or living off investment income. Of the 446 eligible participants, 143 did not complete the questionnaire and were excluded, totaling 303 respondents $(68 \%$ of eligible participants). The presence of outliers was evaluated using Mahalanobis distance; four discrepant observations were excluded, resulting in a final sample of 299 individuals.

The sample consisted predominantly of employees from large companies with over 500 employees $(70 \%)$, privately owned $(71 \%)$, and from the services sector (67\%). Of the total number of respondents, $55 \%$ were men, at an average age of 34, ranging from 22 to 56. All participants had college degrees, and $82 \%$ had completed their graduate studies. The average organizational tenure was 6.5 years, ranging from one to 41 years. Of the total number of participants, $49 \%$ held a management position. These data are shown in Table 2. 
Table 2

\section{Sample characteristics}

\begin{tabular}{|c|c|c|}
\hline Characteristic & $\mathrm{N}=299$ & $\%$ \\
\hline \multicolumn{3}{|l|}{ Gender } \\
\hline Female & 134 & $44.8 \%$ \\
\hline Male & 165 & $55.2 \%$ \\
\hline \multicolumn{3}{|l|}{ Education } \\
\hline College degree & 54 & $18.1 \%$ \\
\hline Graduate education & 245 & $81.9 \%$ \\
\hline \multicolumn{3}{|l|}{ Age } \\
\hline Under 30 & 87 & $29.1 \%$ \\
\hline Between 30 and 39 & 160 & $53.5 \%$ \\
\hline Between 40 and 49 & 39 & $13.0 \%$ \\
\hline 50 or over & 13 & $4.3 \%$ \\
\hline \multicolumn{3}{|l|}{ Management position } \\
\hline No & 152 & $50.8 \%$ \\
\hline Yes & 147 & $49.2 \%$ \\
\hline \multicolumn{3}{|l|}{ Organization type } \\
\hline Public & 86 & $28.8 \%$ \\
\hline Private & 213 & $71.2 \%$ \\
\hline \multicolumn{3}{|l|}{ Organization size } \\
\hline Small / medium & 91 & $30.4 \%$ \\
\hline Large & 208 & $69.6 \%$ \\
\hline \multicolumn{3}{|l|}{ Sector } \\
\hline Services & 199 & $66.6 \%$ \\
\hline Industry & 52 & $17.4 \%$ \\
\hline Others & 48 & $16.1 \%$ \\
\hline
\end{tabular}

\subsection{Measures}

Engagement: engagement was measured by the Utrecht Work Engagement Scale (UWES), developed by Schaufeli and Bakker (2003), which measures three aspects of work engagement vigor, dedication, and absorption - with a sevenpoint scale, ranging from $0=$ never to $6=$ always In this study, we used the Brazilian version of the reduced questionnaire with nine items, validated by Vazquez, Magnan, Pacico, Hutz, and Schaufeli (2015).

\section{Human resource management practices:} based on the literature about high-performance work systems and, in particular, the abilitiesmotivation-opportunity framework (Jiang et al., 2012a, 2012b), a scale with 25 items was created. Since there is no consensus in literature regarding the practices with the greatest impact, we developed a relatively comprehensive set of items that contemplate main human resource management practices. A five-point Likert scale was used, ranging from 1 = totally disagree to $5=$ totally agree.

Leader-member exchange: leadermember exchange quality was measured by the seven-item scale (LMX-7) developed in the 1980s by Graen, Novak, and Summerkamp (Graen \& Uhl-Bien, 1995). It is the most frequently used instrument and includes three dimensions of a leader's exchange with his/her followers - respect, trust, and mutual obligations (Graen \& Uhl-Bien, 1995). The validation of the translated scale used in this study was carried out through principal components factor analysis with oblimin rotation. Only one single factor was found, explaining $68 \%$ of the variance. Barlett's sphericity test was significant, and the Kaiser-Meyer-Olkin (KMO) index (0.918) was within acceptable levels (Hair, Anderson, Tatham, \& Black, 2005).

Core self-evaluations: individual differences were measured by the core selfevaluations scale, created by Judge et al. (2003) and validated for Brazilian samples by Ferreira et al. (2013). The instrument, which encompasses the constructs of self-esteem, self-efficacy, locus of control, and emotional stability, presents 12 items (six positive and six negative), evaluated using a five-point Likert scale, ranging from $1=$ totally disagree to 5 = totally agree.

Turnover intention: turnover intention was measured by a four-item scale, used by Jensen, Patel, and Messersmith (2013) and derived from an earlier study by Tett and Meyer (1993). Again, a five-point Likert scale was used, ranging from 1 $=$ totally disagree to $5=$ totally agree. The validity of the translated scale was tested by principal components factor analysis with oblimin rotation. Only one single factor was found, explaining $76 \%$ of the variance. The $\mathrm{KMO}$ index was adequate (0.825) and Barlett's sphericity test was significant (Hair et al., 2005). 
Control variables: the control variables were gender $(0=$ female, $1=$ male $)$, age, management position $(0=$ no; 1 = yes $)$, organizational tenure (in years), company size (0 = small $/$ medium; 1 = large $)$, and company type $(0=$ public/government, $1=$ private $)$.
The reliability statistics obtained in this study, measured by Cronbach's alpha, are shown in Table 2. Because the values are greater than 0.7 , the scales may be considered adequate (Hair et al., 2005).

Table 3

\section{Reliability statistics}

\begin{tabular}{lcc}
\hline Scale & Cronbach's alpha & Number of items \\
\hline Engagement & 0.959 & 9 \\
HR management practices & 0.945 & 25 \\
Leader-member exchange & 0.919 & 7 \\
Core self-evaluations & 0.814 & 12 \\
Turnover intention & 0.894 & 4 \\
\hline
\end{tabular}

\section{Results}

The research results were organized in three blocks. The first presents descriptive data on HR management practices. The objective was to compare how they were evaluated by the participants. In the second block, we present the correlation analyses of variables and discuss significant correlations, especially between substantive and control variables. Finally, we test the proposed hypotheses, as shown in Figure 1.

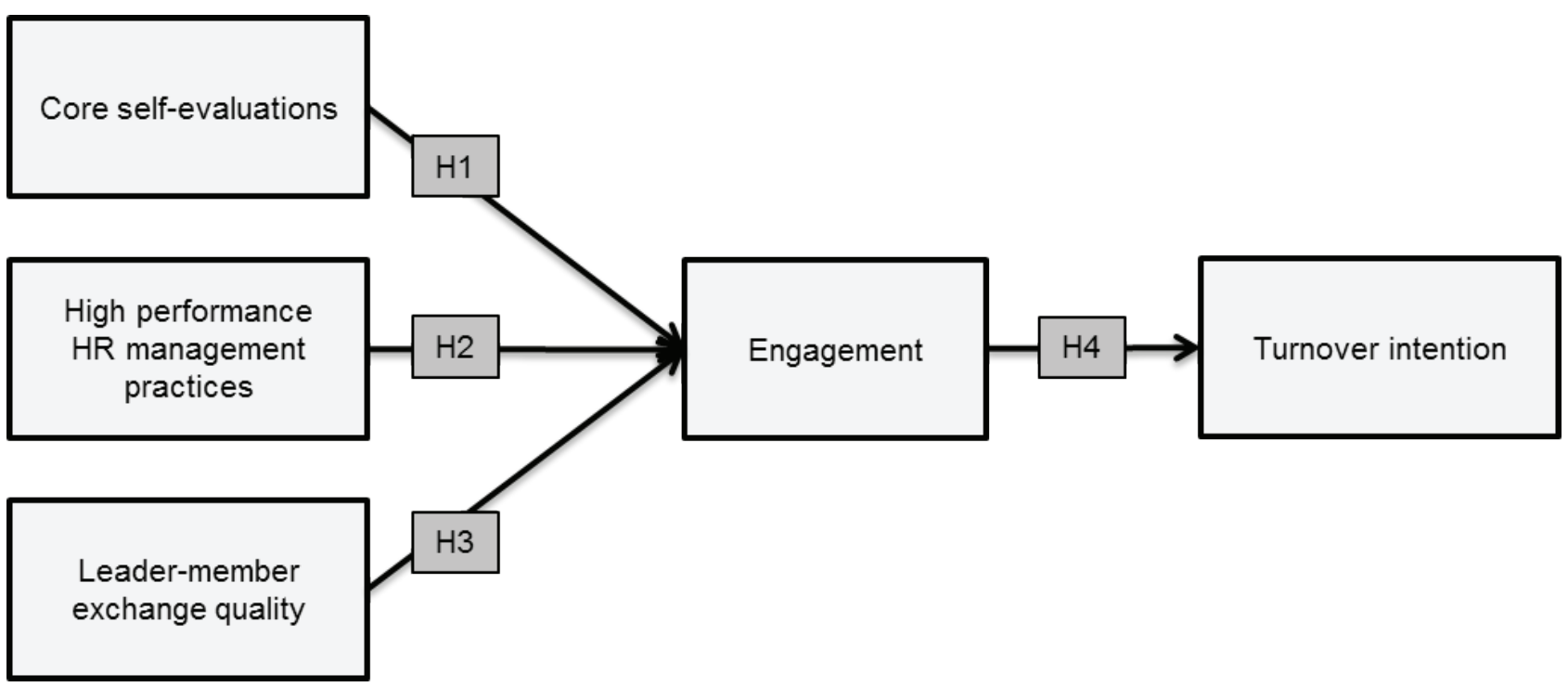

Figure 1. Research model 


\section{I Descriptive analysis of HR management practices}

Twenty-five practices were evaluated in this study, covering different HR management functions or processes. According to the abilitiesmotivation-opportunity model, these practices can be separated into three dimensions, which would respectively impact employee competencies, their motivation and effort, and their opportunities to contribute (Jiang et al., 2012a, 2012b).
Based on these three categories, we analyzed how participants evaluated human resource management practices, as shown in Table 4. Performance appraisal, promotion and career development, and compensation practices showed below-average results. The processes with the best evaluations were training and development, and job security, the latter possibly due to the percentage of respondents working in public companies or government organizations: $29 \%$.

Table 4

\section{Assessment of HR practices}

\begin{tabular}{lcc}
\hline Dimension/Practice & Average (1 to 5 scale) & Standard deviation \\
\hline KSAs & 3.5 & 0.97 \\
Recruitment and selection & 3.4 & 1.10 \\
Training and development & 3.6 & 1.09 \\
Motivation and effort & 3.0 & 1.00 \\
Job security & 3.6 & 1.37 \\
Promotion and career development & 3.0 & 1.19 \\
$\quad$ Performance appraisal & 3.0 & 1.28 \\
$\quad$ Compensation & 3.0 & 1.16 \\
Opportunities to contribute & 3.4 & 0.93 \\
\hline Total average & 3.3 & 0.88 \\
\hline
\end{tabular}

\subsection{Correlation analyses}

Table 5 shows the correlations between the variables under study. HR management practices presented significant and positive correlations with leader-member exchange quality (0.58) and engagement (0.62). HR practices also had a significant and negative correlation with turnover intention (-0.63), a result that indicates that employees who evaluate their HR department positively are less likely to quit. There was also a significant and positive correlation with core selfevaluations, suggesting that individuals who are more positive about themselves tend to evaluate their HR department more favorably. There was also a significant and positive correlation between HR practices and company size (0.18), which indicates that large companies' HR tend to be better evaluated than the small and medium companies' HR, possibly because larger companies have more resources to invest in HR management.

Leader-member exchange quality was positively and significantly related to engagement (0.59), showing that an employee's good relationship with his/her immediate superior tends to contribute to his/her engagement, in line with H3. A significant and negative correlation was observed between leader-member exchange quality and turnover intention (-0.63), corroborating the idea that employees may choose to join an organization based on its characteristics, but may choose to leave it due to their managers. There was also a significant correlation between leader-member exchange quality and core selfevaluations (0.12), suggesting that individuals who are more positive about themselves tend to develop better relationships with their superiors. 
There was a significant and positive correlation between engagement and core selfevaluations (0.33), suggesting that people who are more positive about themselves tend to be more positive towards their work, which would contribute to their engagement, as proposed in H1. There was also a negative and significant correlation between engagement and turnover intention (-0.53), in line with H4.

The positive correlation between company type $(0=$ public and $1=$ private $)$ and turnover intention shows that professionals working in private companies think more frequently about leaving their organizations. This result is not surprising, given that many employees who seek public organizations do so because of job stability (Silva, Balassiano, \& Silva, 2014). The negative correlation between company size $(0=$ small
/ medium, 1 = large) and turnover intention indicates that employees from large companies are less likely to leave them, compared to those working in smaller companies. The perception of the quality of HR management practices, greater in large companies than in smaller ones, may explain this result. Turnover intention was negatively and significantly correlated with tenure $(-0.16)$, and age (-0.13), indicating that older employees and those with longer tenure are less likely to quit, a result that is consistent with the literature (Griffeth et al., 2000).

Finally, there was a significant and positive correlation between core self-evaluations and company type (0.23). This result indicates that professionals from private companies evaluate themselves more positively, compared to those from public companies.

Table 5

Means, standard deviations, and correlations

\begin{tabular}{|c|c|c|c|c|c|c|c|c|c|c|c|c|}
\hline & Average & SD & 1 & 2 & 3 & 4 & 5 & 6 & 7 & 8 & 9 & 10 \\
\hline $\begin{array}{l}\text { 1. } \mathrm{RH} \text { management } \\
\text { practices }\end{array}$ & 3.23 & 0.89 & & & & & & & & & & \\
\hline 2. LMX quality & 3.42 & 0.92 & $.58^{* *}$ & & & & & & & & & \\
\hline 3. Engagement & 3.78 & 1.51 & $.62^{* *}$ & $.59^{* *}$ & & & & & & & & \\
\hline 4. Turnover intention & 2.93 & 1.30 & $-.63^{* *}$ & $-.46^{* *}$ & $-.53^{* *}$ & & & & & & & \\
\hline 5. Core self-evaluations & 3.76 & 0.61 & $.17^{* *}$ & $.12^{*}$ & $.33^{* *}$ & $-.13^{*}$ & & & & & & \\
\hline 6. Company type & 0.71 & 0.45 & -.03 & .03 & .07 & $.26^{* *}$ & $.23^{* *}$ & & & & & \\
\hline 7. Company size & 0.70 & 0.46 & $.18^{* *}$ & -.06 & .09 & $-.23^{* *}$ & .07 & $-.26^{* *}$ & & & & \\
\hline 8. Gender & 0.55 & 0.50 & .05 & .03 & .01 & -.06 & .10 & -.05 & .08 & & & \\
\hline 9. Age & 33.7 & 7.04 & -.05 & -.07 & .01 & $-.13^{*}$ & -.04 & $-.27^{* *}$ & $.15^{* *}$ & $.28^{* *}$ & & \\
\hline 10. Management position & 0.49 & 0.50 & .08 & .08 & $.146^{*}$ & -.10 & .05 & $.12^{*}$ & -.04 & .08 & $.20^{* *}$ & \\
\hline 11. Tenure & 6.48 & 5.66 & .09 & .03 & .05 & $-.16^{* *}$ & -.09 & $-.29^{* *}$ & $.12^{*}$ & $.14^{*}$ & $.48^{* *}$ & $.19^{* *}$ \\
\hline
\end{tabular}

Note: ${ }^{* *}$ The correlation is significant at the 0.01 level (2-tailed); * The correlation is significant at the 0.05 level (2-tailed). 


\subsection{Regression analyses}

Hierarchical regression analyses were used to test the hypotheses about the relationships between engagement and core self-evaluations (H1), employees' perceptions of HR management practices (H2), and leader-member exchange quality (H3), as shown in Table 6.

Table 6

\section{Engagement antecedents}

\begin{tabular}{|c|c|c|c|c|c|}
\hline \multicolumn{2}{|c|}{ Model and variables } & \multirow{2}{*}{$\begin{array}{c}\beta \\
.030\end{array}$} & \multirow{2}{*}{$\frac{\mathbf{t}}{.169}$} & \multirow{2}{*}{$\mathbf{R}^{2}$} & \multirow[t]{2}{*}{$\Delta \mathbf{R}^{2}$} \\
\hline \multirow{6}{*}{1} & Gender & & & & \\
\hline & Age & -.009 & -.606 & \multirow{5}{*}{.04} & \\
\hline & Management position & .383 & $2.129^{*}$ & & \\
\hline & Tenure & .013 & .718 & & \\
\hline & Company type & .281 & 1.339 & & \\
\hline & Company size & .413 & $2.130^{*}$ & & \\
\hline \multirow{7}{*}{2} & Gender & -.068 & -.392 & \multirow{7}{*}{.13} & \multirow{7}{*}{$.09^{* * *}$} \\
\hline & Age & -.008 & -.564 & & \\
\hline & Management position & .361 & $2.112^{*}$ & & \\
\hline & Tenure & .018 & 1.044 & & \\
\hline & Company type & .035 & .170 & & \\
\hline & Company size & .258 & 1.385 & & \\
\hline & Core self-evaluations & .806 & $5.618^{* * *}$ & & \\
\hline \multirow{9}{*}{3} & Gender & -.138 & -1.097 & \multirow{9}{*}{.54} & \multirow{9}{*}{$.41^{* * *}$} \\
\hline & Age & .014 & 1.332 & & \\
\hline & Management position & .196 & 1.561 & & \\
\hline & Tenure & -.003 & -.0219 & & \\
\hline & Company type & .102 & .681 & & \\
\hline & Company size & .102 & .727 & & \\
\hline & Core self-evaluations & .530 & $4.973^{* * *}$ & & \\
\hline & LMX quality & .584 & $7.050^{* * *}$ & & \\
\hline & HR management practices & .651 & $7.414^{* * *}$ & & \\
\hline
\end{tabular}

Note: ${ }^{*} \mathrm{p}<0.05 ;{ }^{* *} \mathrm{p}<0.01 ;{ }^{* * *} \mathrm{p}<0.001$.

Model 1, with only control variables, was not significant. Model 2, which included core self-evaluations, presented a significant coefficient of determination $\left(\mathrm{R}^{2}\right)$ and explained $13 \%$ of the engagement variance. The $\mathrm{R}^{2}$ increase was of $9 \%(\mathrm{p}$ $<0.001)$ and the regression coefficient was positive and significant $(\beta=0.806 ; \mathrm{p}<0.001)$, offering evidence that core self-evaluations are positively related to engagement, as proposed in $\mathrm{H} 1$.

Model 3, which included employees' perceptions of HR management practices and leader-member exchange quality, presented a significant coefficient of determination $\left(\mathrm{R}^{2}\right)$, promoting a considerable increase of $41 \%$ in the explained variance. This result shows that situational variables significantly contribute to engagement, above and beyond individual differences. Considering all variables, model 3 was able to explain $54 \%$ of the engagement variance. The regression coefficients of core self-evaluations $(\beta=0.530, p<0.001)$, HR management practices $(\beta=0.651, p<0.001)$, and leader-member exchange quality $(\beta=0.584, \mathrm{p}<0.001)$ were positive and significant, confirming $\mathrm{H} 1, \mathrm{H} 2$, and 
H3. These results suggest, therefore, that both individual characteristics and situational factors may promote work engagement.

Subsequently, we tested the relationship between engagement and turnover intention (H4), as shown in Table 7. Model 1, which includes only control variables, was significant and presented a coefficient of determination
$\left(\mathrm{R}^{2}\right)$ which explains $11 \%$ of variance. Company type and company size presented a statistically significant relation with turnover intention. More specifically, employees who work for private, small and medium-sized organizations are more likely to leave them, compared to employees from public and large organizations, respectively.

Table 7

\section{Regression analysis of turnover intention}

\begin{tabular}{|c|c|c|c|c|c|}
\hline \multicolumn{2}{|c|}{ Model and variables } & \multirow{2}{*}{$\frac{\beta}{-.032}$} & \multirow{2}{*}{$\frac{\mathbf{T}}{-.212}$} & \multirow[t]{2}{*}{$\mathbf{R}^{2}$} & \multirow[t]{2}{*}{$\Delta \mathbf{R}^{2}$} \\
\hline \multirow{6}{*}{1} & Gender & & & & \\
\hline & Age & -.002 & -.176 & \multirow{5}{*}{$.11^{* * *}$} & \\
\hline & Management position & -.307 & -2.043 & & \\
\hline & Tenure & -.011 & -.714 & & \\
\hline & Company type & .587 & $3.344^{* *}$ & & \\
\hline & Company size & -.494 & $-3.054^{*}$ & & \\
\hline \multirow{7}{*}{2} & Gender & -.017 & -.141 & \multirow{7}{*}{.40} & \multirow{7}{*}{$.29^{* * *}$} \\
\hline & Age & -.006 & -.634 & & \\
\hline & Management position & -.124 & -.999 & & \\
\hline & Tenure & -.005 & -.370 & & \\
\hline & Company type & .721 & $4.979^{* * *}$ & & \\
\hline & Company size & -.298 & $-2.217^{*}$ & & \\
\hline & Engagement & -.477 & $-11.854^{* * *}$ & & \\
\hline
\end{tabular}

Note: ${ }^{*} \mathrm{p}<0.05 ;{ }^{* *} \mathrm{p}<0.01{ }^{* * *} \mathrm{p}<0.001$

Model 2, including the engagement variable, presented a statistically significant coefficient of determination $\left(\mathrm{R}^{2}\right)$ and resulted in a $29 \%$ increase in the explained variance. Therefore, the proposed model was able to explain $40 \%$ of the variance in turnover intention. The regression coefficient of the engagement variable $(\beta=-0.477$; $\mathrm{p}<0.001$ ) was statistically significant, confirming H4. This result suggests that the higher the engagement, the lower an employee's intention to quit. In other words, for this sample, engagement seems to contribute to employee retention.

\section{Discussion and Final considerations}

In this study, we tested hypotheses regarding the relationship between engagement and both individual and situational variables. The results revealed that positive core self-evaluations contribute positively to employee engagement and that, beyond these individual differences, perceptions about HR management practices and leader-member exchange quality also positively influence the engagement level of participants. Furthermore, our results also showed that engagement tends to reduce turnover intention.

From a theoretical perspective, our study is relevant because it contributes to the literature on engagement in the Brazilian context, where there has been relatively little research on the topic. Furthermore, although there is some quantitative research on the antecedents of engagement (Maciel \& Camargo, 2014; Martinelli, Fonseca, \& Silva, 2010), our study 
sets itself apart in that it considers both employees' individual characteristics and situational aspects. In our literature review, we did not find studies conducted in Brazil that analyzed these effects concomitantly.

Since we confirmed the hypothesis that a favorable assessment of HR management practices is positively related to work engagement, there is now more evidence that high-performance HR systems can foster the emergence of positive attitudes at work (Jiang et al., 2012a, 2012b). Furthermore, it highlights the strategic importance of HR management, considering that there is a positive relationship between engagement and performance, as shown in the literature (Bakker et al., 2014; Christian et al., 2011).

The results also show that leadership plays a key role in the engagement of subordinates, which highlights not only the role of leaders in developing a more involved and enthusiastic workforce, but also their contribution to retention, considering the evidence of a negative relationship between engagement and turnover intention. In this sense, HR managers also need to focus on the organization's leaders, both through the selection and training of managers who are genuinely concerned with the quality of the relationship with their subordinates.

The research revealed that engagement is associated with individual differences. Therefore, in the establishment of an engaged workforce, it may be important to develop recruitment strategies that privilege employees who are more positive about themselves. On this subject, correlation analyses have shown that employees from private organizations present higher core self-evaluations than public employees. By attracting employees who are less positive about themselves, and considering the results presented here, these organizations may be creating an environment that is less conducive to engagement. Future research could address this issue.

Finally, we found that engaged employees are less likely to quit their jobs, corroborating evidence found in the literature (Alfes et al., 2013, Harter et al., 2002).

From a practical standpoint, the evidence suggests that investments in high-performance HR management practices and leadership development can benefit organizations, in the form of a more engaged workforce that is, consequently, less willing to quit. In this sense, investing in the promotion of engagement tends to bring another advantage to organizations, given the costs and problems associated with turnover (Cascio \& Boudreau, 2010). In addition, the selection of professionals who are more positive about themselves is also recommended, which may be a problem for public organizations, since public tenders do not take individual differences into account.

This study presents certain limitations. First, we did not analyze each practice or group of HR management practices separately, and chose to focus on participants' perceptions of the whole set of practices adopted by organizations, along with leader-member exchange quality and core selfevaluations. In this sense, future studies should focus on the relative importance of different HR management practices for work engagement. Secondly, because the study was carried out using a convenience sample of employees from a single higher education institution, the results cannot be generalized to the population of college-educated Brazilian employees, the focus of this research. In addition, it should be noted that all variables were measured by the same instrument, at a single moment in time, which is also a limitation. We therefore suggest that further research be carried out on the topic of work engagement, through more sophisticated methodologies, including longitudinal ones.

\section{References}

Alfes, K., Shantz, A., Truss, C., \& Soane, E. (2013). The link between HRM practices, employee engagement and employee behaviors: a 
moderated mediation model. International Journal of Human Resource Management, 24(2), 330-351.

Bakker, A. B. (2011). An evidence-based model of work engagement. Current Directions in Psychological Science, 20(4), 265-269.

Bakker, A. B., Albrecht, S. L., \& Leiter, M. P. (2011). Key questions regarding work engagement. European Journal of Work and Organizational Psychology, 20(1), 4-28.

Bakker, A. B., \& Demerouti, E. (2007). The job demands-resources model: State of the art. Journal of Managerial Psychology, 22(3), 309-328.

Bakker, A. B., \& Demerouti, E. (2008). Towards a model of work engagement. Career Development International, 13(3), 209-223.

Bakker, A. B., Demerouti, E., \& Sanz-Vergel, A. I. (2014). Burnout and work engagement: The JD-R approach. Annual Review of Organizational Psychology and Organizational Behavior, 1(1), 389-411.

Barney, J. B., \& Wright, P. M. (1998). On becoming a strategic partner: The role of human resources in gaining competitive advantage. Human Resource Management, 37(1), 31-46.

Bono, J. E., \& Judge, T. A. (2003). Core selfevaluations: A review of the trait and its role in job satisfaction and job performance. European Journal of Personality, 17(S1), S5-S18.

Cascio, W.; Boudreau, J. (2010). Investimento em Pessoas: como medir o impacto financeiro das iniciativas em recursos humanos. Porto Alegre: Bookman.

Colquitt, J. A., Conlon, D. E., Wesson, M. J., Porter, C. O. L. H., \& Ng, K. Y. (2001).
Justice at the millennium: A meta-analytic review of 25 years of organizational justice research. Journal of Applied Psychology, 86(3), 425-445.

Christian, M. S., Garza, A. S., \& Slaughter, J. E. (2011). Work engagement: A quantitative review and test of its relations with task and contextual performance. Personnel Psychology, 64, 89-136.

Den Hartog, D. N., Boon, C., Verburg, R. M., \& Croon, M. a. (2012). HRM, Communication, Satisfaction, and Perceived Performance: A Cross-Level Test. Journal of Management, 39(6), 1637-1665.

Erez, A., \& Judge, T. A. (2001). Relationship of core self-evaluations to goal setting, motivation, and performance. Journal of Applied Psychology, 86(6), 1270-1279.

Ferreira, M. C., Thadeu, S. H., Masagão, V. C., Gottardo, L. F. S., Gabardo, L. M. D., Sousa, S. A. A., \& Mana, T. C. T. (2013). Escala de avaliaçôes autorreferentes: características psicométricas em amostras brasileiras. Avaliação Psicológica, 12(2), 227-232.

Gerstner, C., \& Day, D. V. (1997). Meta-analytic review of leader-member exchange theory: Correlates and construct issues. Journal of Applied Psychology, 82(6), 827-844.

Graen, G., \& Uhl-bien, M. (1995). Relationshipbased approach to leadership: Development of leader-member exchange (LMX) theory of leadership over 25 years: Applying a multilevel multi-domain perspective. Leadership Quarterly, 6(2), 219-247.

Griffeth, R. W., Hom, P. W., \& Gaertner, S. (2000). a meta-analysis of antecedents and correlates of employee turnover: Update, moderator tests, and research implications for the next millennium. Journal of Management, 26(3), 463-488. 
Guerrero, S., \& Barraud-Didier, V. (2004). Highinvolvement practices and performance of French firms. International Journal of Human Resource Management, 15(8), 1408-1423.

Hair, J. F. Jr.; Anderson, R. E.; Tatham, R. L.; Black, W. C. (2005). Análise multivariada de dados. $5^{\mathrm{a}}$ ed., Porto Alegre: Bookman.

Hallberg, U. E., \& Schaufeli, W. B. (2006). "Same same" but different? Can work engagement be discriminated from job involvement and organizational commitment? European Psychologist, 11(2), 119-127.

Harter, J. K., Schmidt, F. L., \& Hayes, T. L. (2002). Business-unit-level relationship between employee satisfaction, employee engagement, and business outcomes: a metaanalysis. Journal of Applied Psychology, 87(2), 268-79.

Hom, P. W., Caranikas-Walker, F., Prussia, G. E., \& Griffeth, R. W. (1992). A meta-analytical structural equations analysis of a model of employee turnover. Journal of Applied Psychology, 77(6), 890-909.

Jensen, J. M., Patel, P. C., \& Messersmith, J. G. (2013). High-performance work systems and job control: Consequences for anxiety, role overload, and turnover intentions. Journal of Management, 39(6), 1699-1724.

Jiang, K., Lepak, D. P., Hu, J., \& Baer, J. C. (2012a). How does human resource management influence organizational outcomes? A meta-analytic investigation of mediating mechanisms. Academy of Management Journal, 55(6), 1264-1294.

Jiang, K., Lepak, D. P., Han, K., Hong, Y., Kim, A., \& Winkler, A. L. (2012b). Clarifying the construct of human resource systems: Relating human resource management to employee performance. Human Resource Management Review, 22(2), 73-85.
Judge, T. A., Erez, A., Bono, J. E., \& Thoresen, C. J. (2003). The core self-evaluations scale: Development of a measure. Personnel Psychology, 56(2), 303-331.

Judge, T. A., Locke, E. A., \& Durham, C. C. (1997). The dispositional causes of job satisfaction: A core evaluations approach. Research in Organizational Behavior, 19, 151-188.

Kahn, W. A. (1990). Psychological conditions of personal engagement and disengagement at work. Academy of Management Journal, 33(4), 692-724.

Lepak, D. P., Liao, H., Chung, Y., \& Harden, E. E. (2006). A conceptual review of human resource management systems in strategic human resource management research. Research in Personnel and Human Resources Management, 25(6), 217-271.

Macey, W. H., \& Schneider, B. (2008). The meaning of employee engagement. Industrial and Organizational Psychology, 1(1), 3-30.

Maciel, C. D. O., \& Camargo, C. (2014). Conexão social nas organizações: Efeitos dos laços locais no engajamento e no desempenho no trabalho. In Encontro de Estudos Organizacionais da ANPAD. Gramado (RS): ANPAD.

Martinelli, L. A. S., Fonseca, V. S. da, \& Silva, W. V. da. (2010). Engajamento profissional em call centers: Uma análise baseada na teoria dos eventos afetivos. In Encontro Nacional da ANPAD. Rio de Janeiro: ANPAD.

Rich, B. L., Lepine, J. A., \& Crawford, E. R. (2010). Job engagement: Antecedents and effects on job performance. Academy of Management Journal, 53(3), 617-635.

Saks, A. M. (2006). Antecedents and consequences of employee engagement. Journal of Managerial Psychology, 21(7), 600-619. 
Salanova, M., Agut, S., \& Peiró, J. M. (2005). Linking organizational resources and work engagement to employee performance and customer loyalty: The mediation of service climate. Journal of Applied Psychology, 90(6), 1217-27.

Schaufeli, W. B., Salanova, M., Gonzales-Roma, V., \& Bakker, A. B. (2002). The measurement of engagement and burnout: A two sample confirmatory factor analytic approach. Journal of Happiness Studies, 3(1), 71-92.

Schaufeli, W. B., \& Bakker, A. B. (2003). Utrecht work engagement scale: Preliminary manual. Occupational Health Psychology Unit, Utrecht University, Utrecht.

Schriesheim, C. A., Castro, S. L., \& Cogliser, C. C. (1999). Leader-member exchange (LMX) research: A comprehensive review of theory, measurement and data-analytic practices. Leadership Quarterly, 10(1), 63-113.

Shuck, B., \& Wollard, K. (2010). Employee engagement and HRD: A seminal review of the foundations. Human Resource Development Review, 9(1), 89-110.

Silva, J. R., Balassiano, M., \& Silva, A. R. L. (2014). Burocrata Proteano: Articulações de Carreira em torno e além do Setor Público. RAC - Revista de Administração Contemporânea, 18(1), 1-19.
Sun, L.-Y., Aryee, S., \& Law, K. S. (2007). Highperformance human resource practices, citizenship behavior, and organizational performance: A relational perspective. Academy of Management Journal, 50(3), 558-577.

Tett, R. P., \& Meyer, J. P. (1993). Job satisfaction, organizational commitment, turnover intention, and turnover: Path analyses based on meta-analytic findings. Personnel Psychology, 46(2), 259-293.

Vazquez, A. C. S., Magnan, E. dos S., Pacico, J. C., Hutz, C. S., \& Schaufeli, W. B. (2015). Adaptation and validation of the Brazilian version of the Utrecht Work Engagement Scale. Psico-USF, 20(2), 207-217.

Warr, P., \& Inceoglu, I. (2012). Job engagement, job satisfaction, and contrasting associations with person-job fit. Journal of Occupational Health Psychology, 17(2), 129-138.

Xanthopoulou, D., Bakker, A. B., Demerouti, E., \& Schaufeli, W. B. (2007). The role of personal resources in the job demandsresources model. International Journal of Stress Management, 14(2), 121-141.

Xanthopoulou, D., Bakker, A. B., Demerouti, E., \& Schaufeli, W. B. (2009). Reciprocal relationships between job resources, personal resources, and work engagement. Journal of Vocational Behavior, 74(3), 235-244. 


\section{About the Authors:}

1. Lucia Barbosa de Oliveira, PhD. in Management. Instituto Coppead de Administração/Federal University of Rio de Janeiro, Brazil. E-mail: loliveira@ibmec.edu.br.

2. Juliana da Costa Rocha, Master in Management. School of Economics and Finance, Ibmec-RJ, Brazil. E-mail: jucostarocha@gmail.com.

\section{Contribution of each author}

\begin{tabular}{lcc}
\hline Contribution & Lucia Barbosa de Oliveira & Juliana da Costa Rocha \\
\hline 1. Definition of research problem & $\sqrt{ }$ & $\sqrt{ }$ \\
2. Development of hypotheses or research questions (empirical studies) & $\sqrt{ }$ \\
3. Development of theoretical propositions (theoretical Work) & \\
4. Theoretical foundation / Literature review & $\sqrt{ }$ \\
5. Definition of methodological procedures & $\sqrt{ }$ \\
6. Data collection & \\
7. Statistical analysis & $\sqrt{ }$ \\
8. Analysis and interpretation of data & $\sqrt{ }$ \\
9. Critical revision of the manuscript & $\sqrt{ }$ \\
10. Manuscript Writing & $\sqrt{ }$ \\
\hline
\end{tabular}

